\title{
Tenascin in cerebrospinal fluid is a useful biomarker for the diagnosis of brain tumour
}

\author{
J Yoshida, T Wakabayashi, S Okamoto, S Kimura, K Washizu, K Kiyosawa, K Mokuno
}

\begin{abstract}
Tenascin, an extracellular matrix glycoprotein, has been reported to be expressed predominantly on glioma tissue in the CNS, both in a cell associated and an excreted form. Recently, a highly sensitive sandwich type enzyme immunoassay for quantitative determination of tenascin was developed. In the present study, the amount of tenascin in CSF was measured. An increase of tenascin in CSF (>100 $\mathrm{ng} / \mathrm{ml}$ ) was found in patients with an astrocytic tumour. The concentration was significantly higher (>300 $\mathrm{ng} / \mathrm{ml}$ ) in high grade astrocytoma (anaplastic astrocytoma and glioblastoma) and $a$ further increase (>1000 $\mathrm{ng} / \mathrm{ml}$ ) was found in cases of CSF dissemination of high grade astrocytoma. On the other hand, tenascin concentrations were less than $100 \mathrm{ng} / \mathrm{ml}$ in nonastrocytic tumours and non-neoplastic neurological diseases, except meningeal dissemination of tumour cells, meningeal stimulation by infection, and subarachnoid haemorrhage. In cases of treated astrocytomas in remission, tenascin was negligible ( $<100 \mathrm{ng} / \mathrm{ml}$ ) in the CSF. The measurement of tenascin in CSF is useful for differential diagnosis of brain tumours and monitoring of astrocytic tumours.
\end{abstract}

(F Neurol Neurosurg Psychiatry 1994;57:1212-1215)

Neurosurgery, Nagoya

University School of

Medicine, Nagoya,

Japan

J Yoshida

T Wakabayashi

S Okamoto

Department of

Research and

Development, Amano

Pharmaceutical

Company, Aichi,

Japan

S Kimura

K Washizu

Department of

Neurology, Nagoya

University School of

Medicine, Nagoya,

Japan

K Kiyosawa

K Mokuno

Correspondence to:

Dr Jun Yoshida,

Department of

Neurosurgery, Nagoya

University School of

Medicine, 65 Tsurumaicho, Showa-ku, Nagoya, 466 Japan.

Received 19 March 1993 and in final revised form 28 January 1994.

Accepted 1 March 1994

Tenascin is an extracellular matrix glycoprotein involved in tissue interaction during fetal development and oncogenesis. ChiquetEhrismann et al reported that tenascin was present in the mesenchyme of the fetal rat mammary gland but not in the adult mammary gland. The protein was, however, predominantly re-expressed in carcinogen induced mammary tumours. ${ }^{1}$ This extracellular matrix glycoprotein was discovered independently by several laboratories, each showing a different aspect of its biology, and each giving it a different name: myotendinous antigen, ${ }^{2}$ glioma mesenchymal extracellular matrix antigen, ${ }^{3} \mathrm{~J} 1$ glycoprotein, ${ }^{4}$ cytotactin, ${ }^{5}$ hexabrachion, ${ }^{6}$ and tenascin. ${ }^{1}$ Bourdor et al reported a glioma mesenchymal extracellular matrix antigen defined by monoclonal antibody $81 \mathrm{C6}$, which binds an extracellular matrix antigen shared by glioma and mesenchymal cell lines but not carcinoma, myeloid, or lymphoid cell lines. ${ }^{7}$
Subsequently, Erikson and Taylor showed that this was biochemically identical with tenascin. ${ }^{6}$ Within the CNS the use of peroxidase antiperoxidase immunohistology with 81C6 MCA showed that the antigen was expressed in glioblastomas but not in astrocytomas or in normal adult brain. ${ }^{7}$

In 1991, Herlyn et al found that most melanoma cells secreted tenascin in vitro. They also reported that tenascin was present in the serum of patients with melanoma and that the concentration of tenascin in serum was a tumour marker for advanced melanomas because they found lower concentrations in patients with low tumour burden and in normal donors. ${ }^{8}$ Recently, we developed a sandwich type enzyme immunoassay for tenascin ${ }^{9}$ and showed, with this assay system, that not only human melanoma, but also human lung cancer and glioma cells secreted $1-14 \mu \mathrm{g} / \mathrm{ml}$ of tenascin in vitro (data not shown). In the present study, serum and CSF were obtained from patients with various neoplastic and non-neoplastic neurological diseases, and the amount of tenascin was quantitatively determined. It was expected that an increased level of expression of this extracellular matrix glycoprotein would be found in neoplasms compared with other diseases of the CNS, and that the level of expression would be useful in indicating the type of brain tumour.

\section{Patients and methods}

SANDWICH TYPE ENZYME IMMUNOASSAY
Details of the methodology of the sandwich type enzyme immunoassay for tenascin has been reported elsewhere. 9 Briefly, an antiserum to human tenascin was raised in rabbits. Two antihuman tenascin monoclonal antibodies, $8 \mathrm{C} 9$ (RCB1) $^{10}$ and 9B2, were supJapan and $F(a b)^{\prime} 2$ fragments of both antibodies, prepared from 1gG by pepsin digestion, were used. The RCB1 fragment was immobilised non-covalently on polystyrene beads and the 9B2 fragment was coupled to $\beta$-Dgalactosidase. Polystyrene beads with antibodies were incubated with various amounts of purified tenascin or samples of serum and CSF $(10 \mu \mathrm{l})$ in a final volume of $0.51 \mathrm{ml}$ with sodium phosphate buffer for three hours. After washing twice with buffer, the beads D-galatosidase labelled antibodies (mixed 0.5 tion at $4^{\circ} \mathrm{C}$. Beads were again washed twice plied by Amano Pharmaceutical Co, Aichi, were left standing overnight with $1 \mathrm{mU}$ of $\beta$ $\mathrm{mU}$ of $8 \mathrm{C} 9$ and $9 \mathrm{~B} 2$ ) in $0.2 \mathrm{ml}$ of buffer solu- 
Table 1 Concentrations of tenascin in CSF ( $\mathrm{ng} / \mathrm{ml})$

\begin{tabular}{llllll}
\hline Disease & $n$ & $\begin{array}{l}\text { Negligible } \\
(<100)\end{array}$ & $\begin{array}{l}\text { Low } \\
(100-300)\end{array}$ & $\begin{array}{l}\text { Medium } \\
(300-1000)\end{array}$ & $\begin{array}{l}\text { High } \\
(>1000)\end{array}$ \\
\hline Non-neoplastic disease & 57 & 54 & 3 & 0 & 0 \\
Pituitary adenoma & 10 & 10 & 0 & 0 & 0 \\
Craniopharyngioma & 2 & 2 & 0 & 0 & 0 \\
Neurinoma & 2 & 2 & 0 & 0 & 0 \\
Meningioma & 6 & 5 & $1 \neq$ & 0 & 0 \\
Germ cell tumour & 4 & 4 & 0 & 0 & 0 \\
Pineoblastoma & 1 & 1 & 0 & 0 & 0 \\
CNS lymphoma & 1 & 0 & 1 & 0 & 0 \\
Oligodendroglioma & 1 & 1 & 0 & 0 & 0 \\
Ependymoma & 1 & 1 & 0 & 0 & 0 \\
Medulloblastoma & 2 & 1 & 0 & $10^{\star}$ & 0 \\
Astrocytoma & 5 & $1 \dagger$ & 4 & 0 & 0 \\
Anaplastic astrocytoma & 5 & $1 \dagger$ & 0 & 3 & $1^{\star}$ \\
Glioblastoma & 9 & $2 \dagger$ & 3 & 2 & $2^{\star}$ \\
Brainstem glioma & 6 & $3 \dagger$ & 1 & 2 & 0 \\
Metastatic brain tumour & 3 & 1 & 1 & 1 & 0 \\
\hline
\end{tabular}

^Associated with CSF dissemination.

†Postoperative state after radiotherapy or chemotherapy.

$\ddagger$ Meningeal sarcoma.

SMeningitis, subarachnoid haemorrhage, normal pressure hydrocephalus.

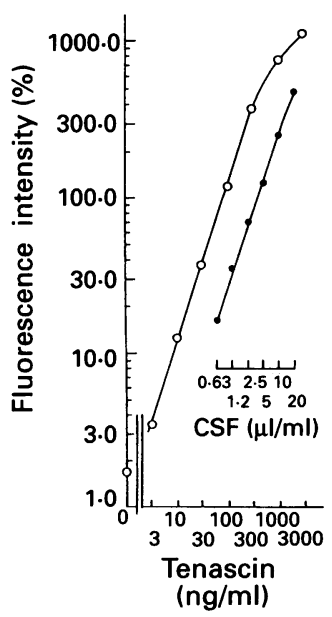

Figure 1 Standard curve and CSF dilution curve for sandwich enzyme immunoassay of tenascin. Each point represents the mean of a duplicate assay.
Table 2 Numbers of patients with non-neoplastic diseases

\begin{tabular}{ll}
\hline Non-neoplastic disease & $n$ \\
\hline Cerebral infarction & 9 \\
Intracerebral haemorrhage & 1 \\
Subarachnoid haemorrhage & 3 \\
Meningitis or encephalitis & 9 \\
Cervical or lumbar spondylosis & 9 \\
Multiple sclerosis & 4 \\
Spinocerebellar degeneration & 6 \\
Amyotrophic lateral sclerosis & 1 \\
Parkinson's disease & 1 \\
Huntington's disease & 1 \\
Bulbospinal muscular atrophy & 1 \\
Neuropathy & 3 \\
Dementia & 1 \\
Involuntary movement & 1 \\
Normal pressure hydrocephalus & 1 \\
Aneurysm & 2 \\
Radiation necrosis & 1 \\
Arachnoid cyst & 1 \\
Tuberculosis & 1 \\
Head injury & 1
\end{tabular}

astrocytoma or glioblastoma $(n=14)$. The concentrations of tenascin were statistically different between the groups. (fig 2) In the non-astrocytic group, tenascin in CSF was less than $100 \mathrm{ng} / \mathrm{ml}$ except for three tumours (10\%) each with CSF dissemination. More than $100 \mathrm{ng} / \mathrm{ml}$ of tenascin was detected in 15 cases $(79.0 \%)$ in the astrocytic tumour group. In three metastatic tumours, the level was $249.7 \mathrm{ng} / \mathrm{ml}$ in meningeal carcinomatosis of gastric cancer, $771.7 \mathrm{ng} / \mathrm{ml}$ in metastatic parietal tumour of lung cancer, but only 45.5 $\mathrm{ng} / \mathrm{ml}$ in an extradural skull base undifferentiated carcinoma. We classified the concentration of tenascin in CSF into four groups; negligible if less than $100 \mathrm{ng} / \mathrm{ml}$, low if 100-300 ng/ml, medium when 300-1000 $\mathrm{ng} / \mathrm{ml}$, and high for more than $1000 \mathrm{ng} / \mathrm{ml}$ (table 1). In low grade astrocytoma, $80 \%$ of the tumours expressed low concentrations of tenascin and, none of them had medium or high concentrations, whereas more than $50 \%$ of high grade astrocytomas (anaplastic astrocytoma or glioblastoma) expressed medium or high concentrations. Furthermore, all patients with high expression of tenascin showed CSF with chilled buffer and the galactosidase activity bound was measured after incubation at $37^{\circ} \mathrm{C}$ for 30 minutes with $0.15 \mathrm{mmol}$ 4-methylumbelliferyl $\beta$-D-galactoside (Sigma St Louis, MO, USA) as a substrate.

\section{SAMPLES}

Serum samples were obtained from two healthy donors and 10 patients with brain tumours. Samples of CSF were taken from patients with various neurological diseases by spinal tap or puncture of an Ommaya reservoir connected to the lateral ventricle. Fifty eight patients had brain tumours. (table 1) Samples of CSF from four patients were taken serially and the concentrations of tenascin were compared with the tumour progression and regression. Fifty seven patients had nonneoplastic neurological disease (table 2). Brain tumour cystic fluid was also obtained from eight patients at surgery or by puncture of an Ommaya reservoir connected to the cyst.

\section{Results}

STANDARD CURVE

Figure 1 shows a standard curve for our sandwich type enzyme immunoassay of tenascin. The minimum detectable amount of tenascin was $0.1 \mathrm{ng}$ per assay tube or $10 \mathrm{ng} / \mathrm{ml}$. A linear dose response of the absorbance $v$ tenascin added was obtained at between $0 \cdot 1$ to $30 \mathrm{ng}$ per assay tube. The results for diluted CSF samples were parallel with the standard curve.

\section{CEREBROSPINAL FLUID}

Table 1 shows the concentrations of tenascin in CSF obtained from patients with various neurological diseases. For non-neoplastic disease, 54 patients $(94.8 \%)$ had tenascin concentrations of less than $100 \mathrm{ng} / \mathrm{ml}$ and most were less than $50 \mathrm{ng} / \mathrm{ml}$. Only three patients $(5 \cdot 2 \%)$ had concentrations above $100 \mathrm{ng} / \mathrm{ml}$ : post-subarachnoid haemorrhage $(186 \mathrm{ng} / \mathrm{ml})$, meningitis $(188 \mathrm{ng} / \mathrm{ml})$, and normal pressure hydrocephalus (136 ng/ml). For neoplastic disease, we divided primary brain tumours into three subgroups; non-astrocytic $(n=30)$, low grade astrocytoma $(n=5)$, and anaplastic

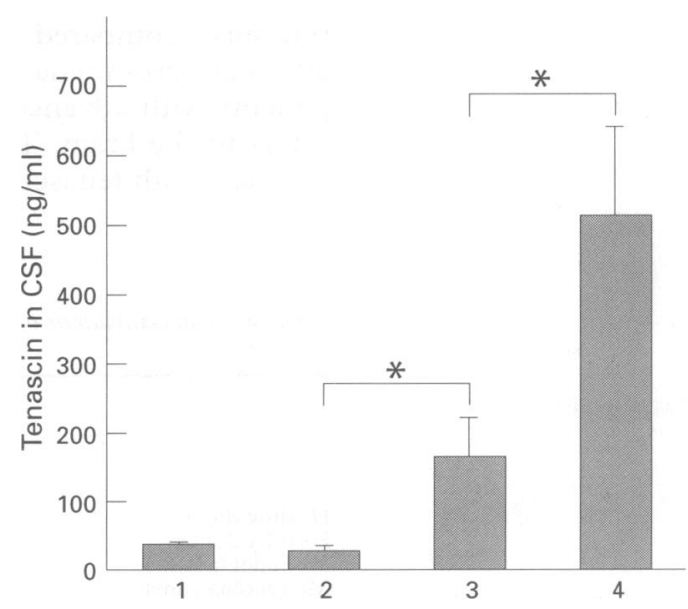

Figure 2 Concentrations of tenascin in CSF obtained from patients with neoplastic and non-neoplastic CNS diseases. (1) Non-neoplastic disease (36.32 (SD 4.36), $n=57) ;(2)$ non-astrocytic brain tumour (30.35 (6.66) $n=30)$; (3) low grade astrocytoma (166.36 (52.53),

$n=5)$, (4) anaplastic astrocytoma or glioblastoma (506.94 (125.75), $n=14)$. ${ }^{*} p<0.05$; Welch's $t$ test. 
Table 3 Concentrations of tenascin in cystic fluid of brain tumours

\begin{tabular}{lr}
\hline Tumour type & $\begin{array}{l}\text { Tenascin } \\
\text { (ng/ml) }\end{array}$ \\
\hline Cystic menigioma & $263 \cdot 9$ \\
Haemangioblastoma & $457 \cdot 8$ \\
Astrocytoma (optic glioma) & $1010 \cdot 3$ \\
Metastatic lung cancer & $2152 \cdot 0$ \\
Metastatic lung cancer & $32172 \cdot 5$ \\
Craniopharyngioma & $20860 \cdot 5$ \\
Craniopharyngioma & $22496 \cdot 5$ \\
Glioblastoma & $\mathbf{4 5 6 6 7 \cdot 4}$ \\
\hline
\end{tabular}

dissemination of their high grade astrocytoma. For this group of patients, negligible tenascin expression was only found in the CSF of postoperative patients who had received some radiotherapy or chemotherapy.

Samples of CSF were also serially taken from four patients with a primary brain tumour. In an embryonal carcinoma of the supersellar region and a pineoblastoma, negligible tenascin $(9.4$ and $48.2 \mathrm{ng} / \mathrm{ml})$ increased to low-expression (220.7 and $234.9 \mathrm{ng} / \mathrm{ml}$ ) with CSF dissemination of the tumour cells. In a patient with malignant lymphoma, a low level of tenascin $(132 \cdot 7 \mathrm{ng} / \mathrm{ml})$ became negligible $(57.6 \mathrm{ng} / \mathrm{ml})$ in accordance with regression of the tumour after chemotherapy. In a patient in whom an astrocytoma was totally removed, tenascin in CSF was negligible $(28.9 \mathrm{ng} / \mathrm{ml})$ and continued to be negligible $(37.8 \mathrm{ng} / \mathrm{ml})$ after a seizure, at which time CT confirmed continued remission of the tumour.

CYSTIC FLUID

Table 3 summarises the tenascin concentrations in cystic fluid from brain tumours. It was low in a meningioma and a haemangioblastoma, and high in an astrocytoma, metastatic tumours, and a glioblastoma. In craniopharyngiomas, tenascin in tumour cysts was very high $(>20000 \mathrm{ng} / \mathrm{ml})$, but was less than $100 \mathrm{ng} / \mathrm{ml}$ in CSF.

\section{SERUM}

Serum concentrations of tenascin were 733 to $4853 \mathrm{ng} / \mathrm{ml}$ (table 4 ). They were not significantly increased in patients with primary brain tumours compared with healthy donors, although serum tenascin was relatively high in patients with advanced carcinoma and metastases to the brain. Tenascin in CSF did not correlate with tenascin in serum.

Table 4 Concentrations of tenascin in patients with brain tumours

\begin{tabular}{lll}
\hline & \multicolumn{2}{l}{ Tenascin } \\
\cline { 2 - 3 } & $\begin{array}{l}\text { Serum } \\
(\mathrm{ng} / \mathrm{ml})\end{array}$ & $\begin{array}{l}\text { CSF } \\
(\mathrm{ng} / \mathrm{ml})\end{array}$ \\
\hline Healthy donor & 1136 & - \\
Healthy donor & 1657 & - \\
Medulloblastoma & 1563 & - \\
Medulloblastoma & 1672 & - \\
Astrocytoma & 2016 & 130 \\
Anaplastic astrocytoma & 988 & 522 \\
Anaplastic astrocytoma & 733 & 652 \\
Brainstem glioma & 1108 & 576 \\
Diffuse gliomatosis & 796 & - \\
Glioblastoma & 1434 & - \\
Metastatic gall bladder carcinoma & 3035 & - \\
Metastatic lung cancer & 4853 & - \\
\hline
\end{tabular}

\section{Discussion}

Human tenascin has two major isoforms, with molecular weights of $320 \mathrm{kDa}$ and $220-230$ $\mathrm{kDa}{ }^{1{ }^{12}}$ Ventimiglia et al found no difference in electrophoretic mobility of glioma specific isoforms and those of the normal brain. ${ }^{12}$ They also indicated that both $320 \mathrm{kDa}$ and $220 \mathrm{kDa}$ isoforms were expressed not only in glioma cells but also in normal adult brain other than the cerebellum. Despite the presence of tenascin in the normal human brain, 8IC6 anti-tenascin monoclonal antibody did not show significant specific binding to normal brain in either immunohistochemical studies of normal human brain sections or in in vivo localisation studies with a radiolabelled 8IC6 monoclonal antibody in patients with brain tumours. These researchers considered that this was due to differences in the quantitative expression of tenascin between normal and malignant tissues.

It has also been reported that tenascin is expressed in a secreted form, and the amount of secreted tenascin has been measured by various quantitative assay systems. A tenascin concentration of $5-10 \mu \mathrm{g} / \mathrm{ml}$ was detected in culture of human glioma cells by Erikson and Lightner, ${ }^{13} 3-18 \mu \mathrm{g} / \mathrm{ml}$ by Ventimiglia et $a l^{12}$ and $1-14 \mu \mathrm{g} / \mathrm{ml}$ in our study. In the present study, we determined the amount of tenascin in serum, intratumoural cystic fluids, and CSF in patients with glioma and compared these concentration with those from patients with non-gliomatous brain tumours and nonneoplastic diseases. Our highly sensitive sandwich type enzyme immunoassay has already been described by Washizu et al. ${ }^{9}$ The assay system has a minimum detectable sensitivity of $0.1 \mathrm{ng}$ per assay tube or $10 \mathrm{ng} / \mathrm{ml}$ and no cross reactivities with laminin, vitronectin, hEGF, fibrinogen, and fibronectin. Our present results indicate that the serum concentration of tenascin is not useful for the diagnosis of brain tumours except metastases. The quantitative determination of tenascin in CSF proved useful, however, for the diagnosis and monitoring of gliomas. A negligible expression of tenascin was found in patients with nonneoplastic disease or non-gliomatous tumours. The expression of tenascin seen in patients with gliomas depended on the grade of the tumour and the progress of the disease. A tenascin concentration of greater than 100 $\mathrm{ng} / \mathrm{ml}$ suggests an astrocytic tumour, low grade if values are $100-300 \mathrm{ng} / \mathrm{ml}$ and high grade if they are $300-1000 \mathrm{ng} / \mathrm{ml}$. A tenascin concentration greater than $1000 \mathrm{ng} / \mathrm{ml}$ suggests CSF dissemination of a high grade glioma. Interestingly, negligible concentrations of tenascin were found in patients in whom high grade tumours had been treated with surgery, radiation, or chemotherapy, and who were in clinical remission.

High concentrations of tenascin were found in cyst fluid from an astrocytic tumour as well as a craniopharyngioma. The CSF concentration in the patient with the astrocytic tumour was high whereas that in the patient with the cranipharyngioma was low, however, possibly due to the presence of the craniopharyngioma 
tumour capsule. Pseudopositive tenascin concentrations (>100 ng/ml) were found in conditions of meningeal irritation such as meningitis and subarachnoid haemorrhage. It is possible that some tenascin may be secreted from reactive fibroblasts, astrocytes, or endothelial cells.

In a previous study, we reported that a radiommunoassay of glioma associated antigen (G-22) in CSF was useful for the diagnosis and monitoring of human gliomas. ${ }^{14}$ This assay is, however, cumbersome and fails to differentiate between high grade glioma and medulloblastoma. The new method reported here is easy and practical for differentiation of brain tumours, and monitoring of the disease state in treated patients.

1 Chiquet-Ehrismann R, Mackie E, Pearson C, et al. Tenascin: An extra-cellular matrix protein involved in Tenascin: An extra-cellular matrix protein involved in
tissue interactions during fetal development and oncogetissue interactions during fe
nesis. Cell 1986;47:131-49.

2 Chiquet M, Fambrough DM. Chick myotendinous antigen. I. A monoclonal antibody as a marker for tendon and muscle morphogenesis. $f$ Cell Biol 1984;98: 1926-36.

3 Bourdon MA, Matthews TJ, Pizzo SV, et al. Immunochemical and biochemical characterization of a glioma-associated extracellular matrix glycoprotein. f Cell Biochem 1985;28:183-95.
4 Kruse J, Keilhauer G, Faissner A, et al. The J1 glycoprotein: a novel nervous system cell adhesion molecule of the L2/HNK-1 family. Nature 1985;316:146-8.

5 Grumet M, Hoffmann S, Crossin KL, et al. Cytotactin, an extra-cellular matrix protein of neural and non-neural tissues that mediates glia-neuron interaction. Proc Natl Acad Sci USA 1985;82:8075-9.

6 Erickson HP, Taylor HC. Hexabrachion proteins in embryonic chicken tissues and human tumors. F Cell Biol 1987;105:1387-94.

7 Bourdon MA, Wikstrand CJ, Furthmayr $\mathrm{H}$, et al. Human glioma-mesenchymal extracellular matrix antigen glioma-mesenchymal extracellular matrix antigen
defined by monoclonal antibody. Cancer Res 1983;43: defined by

8 Herlyn M, Graeven V, Speicher D, et al. Characterization of tenascin secreted by human melanoma cells. Cancer Res 1991;51:4853-8

9 Washizu K, Kimura S, Hiraiwa H, et al. Development and application of enzyme immunoassay for detecting tenascin. Clin Chim Acta 1994;219:15-22.

10 Oike $\mathrm{Y}$, Hiraiwa $\mathrm{H}$, Kawakatsu $\mathrm{H}$, et al. Isolation and characterization of human fibroblast tenascin. An extracellular matrix glycoprotein of interest for developmental studies. Int $\mathscr{f}$ Dev Biol 1990;34:309-17.

11 Lightner. VA, Gumkowski F, Bigner DD, et al. Tenascin/hexabrachion in human skin:biochemical identification and localization by light and electron microscopy. f Cell Biol 1989;108:2483-93.

12 Ventimiglia JB, Wikstrand CJ, Ostrowski LE, et al. Tenascin expression in human glioma cell lines and norTenascin expression in human glioma cell lines
mal tissues. $¥$ Neuroimmunol 1992;36:41-55.

13 Erickson. HP, Lightner VA. Hexabrachion protein (tenascin, cytotactin, and brachionectin) in connective tissue, embryonic brain, and tumors. Adv Cell Biol 1988; 2:55-90.

14 Yoshida J, Yamamoto $\mathrm{R}$, Wakabayashi $\mathrm{T}$, et al. Radioimmunoassay of glioma-associated antigen in cerebrospinal fluid and its usefulness for the diagnosis and monitoring of human glioma. fournal of Neuro-Oncology 1990;8:23-31. 